\title{
MAHKAMAH SYAR'IYAH DAN WILAYATUL HISBAH SEBAGAI GARDA TERDEPAN DALAM PENEGAKAN QANUN JINAYAT DI ACEH
}

\author{
Ali Geno Berutu \\ IAIN Salatiga \\ ali_geno@ymail.com
}

\begin{abstract}
Legal effectiveness is a process that aims so that the law can be effective. Synergize between what is in the rules of a number of rules for the creation, maintenance and maintenance of peace in social life. This situation can be reviewed on the basis of several measures of effectiveness. According to Soerjono Soekanto, the main problem in law enforcement is located in its own law (the prevailing laws and regulations), law enforcers, namely those who oversee the application of law, facilities or facilities that support the application of law, the community where the law is applied and legal culture in the community. These five factors are closely related due to the essence of law enforcement. The five factors are a benchmark of the effectiveness of the application of the law. In this article the author tries to describe the functions of the Sharia law enforcement institutions in Aceh, namely the Mahkamah Syar'iyah and Wilayatul Hisbah.
\end{abstract}

\begin{abstract}
Abstrak
Efektivitas hukum merupakan proses yang bertujuan supaya hukum dapat berlaku efektif. Menserasikan antara apa yang ada di dalam kaidah-kaidah sejumlah peraturan-peraturan terhadap penciptaan, pemeliharaan dan mempertahankan kedamaian dalam pergaulan hidup. Keadaan tersebut dapat di tinjau atas dasar beberapa tolok ukur efektivitas. Menurut Soerjono Soekanto masalah pokok dalam penegakan hukum adalah terletak pada hukumnya sendiri (peraturan perundang-undangan yang berlaku), penegak hukumnya yakni pihak-pihak yang mengawal penerapan hukum, sarana atau fasilitas yang mendukung penerapan hukum, masyarakat di mana hukum tersebut diberlakukan dan budaya hukum dalam masyarakatnya. Kelima faktor tesebut saling memiliki kaitan yang erat dikarenakan esensi dari penegakan hukum. Kelima faktor tersebut merupakan tolak ukur daripada efektifitas penerapan hukum. Pada artikel ini penulis mencoba menguraikan fungsi lembaga penegak hukum syariat di Aceh yakni Mahkamah Syar'iyah dan Wilayatul Hisbah.
\end{abstract}

Kata Kunci: Mahkamah Syar'iyah, Wilayatul Hisbah, Aceh, Qanun, Syariat Islam

\section{A. Latar Belakang Masalah}

Pemberlakuan syariat Islam di Aceh secara formal dilakukan setelah keluarnya UU No. 44 Tahun 1999 dan UU No. 18 Tahun 2001, hal mendasar dari dari undang-undang ini adalah adanya pemberian kesempatan yang luas untuk mengatur dan mengurus rumah tangga sendiri, meggali dan memberdayakan sumber daya alam dan sumber daya manusia, meningkatkan peran serta masyarakat, menggali dan mengimplementasikan tata kehidupan bermasyarakat yang sesuai dengan nilai luhur kehidupan bermasyarakat di Aceh. Pengertian syariat Islam di 
Aceh menurut UU No. 44 Tahun 1999 adalah tuntutan ajaran Islam dalam semua aspek kehidupan, Syariat Islam dipraktekkan secara luas mencakup aspek pendidikan, kebudayaan, politik, ekonomi dan aspek-aspek lainnya.

Pemerintah Aceh sesuai dengan amant UU No. 18 Tahun 2001 tentang Otonomi Khusus bagi Propinsi Daerah Istimewa Aceh sebagai Propinsi Nanggroe Aceh Darussalam (NAD) dapat membuat qanun-qanun Aceh yang bersifat lex specialist ${ }^{l}$ (hukum yang berlaku khusus) dalam rangka penyelenggaraan hak otonomi khusus. Pemberlakuan syariat Islam secara konstitusional pada bidang jinayah secara resmi diberlakukan di Aceh pada tahun 2003 yaitu dengan diterbitkannya Qanun No. 12 Tahun 2003 tentang larangan minuman khamar dan sejenisnya, Qanun No. 13 tahun 2003 tentang Maisir, dan Qanun No. 14 tahun 2003 tentang Khalwat. $^{2}$

Sebagai produk perundangan daerah menyusul diberlakukannya Otonomi Khusus bagi Aceh, maka qanun-qanun tersebut dilindungi oleh undang-undang, yaitu UU Nomor 44 tahun 1999 tentang Penyelenggaraan Keistimewaan Aceh pasal 3 dan $4,{ }^{3}$ UU Nomor 18 tahun 2001 tentang Otonomi Khusus bagi Aceh dan UU Nomor 11 tahun 2006 tentang Pemerintahan Aceh bab 17-18. ${ }^{4}$ UU No. 44/1999 pasal 12 dijelaskan bahwa, peraturan perundang-undangan yang bertentangan dan atau tidak sesuai dengan UU tersebut dinyatakan tidak berlaku.

Selain itu qanun di Aceh juga dilindungi oleh UU Pemerintahan Aceh, pada pasal 269 dijelaskan bahwa peaturan perundang-undangan yang ada pada saat UU Pemerintah Aceh diundangkan tetap berlaku sepanjang tidak bertentangan dengan undang-undang ini. Untuk mendukung kelangsungan pemberlakuan syariat Islam di Aceh, maka Pemerintah Aceh telah membentuk lembaga-lembaga penegak syariat Islam di daerah tersebut seperti, Dinas Syariat Islam, Mahkamah Syar'iyah, Wilayatul Hisbah, Majelis Adat Aceh dan lembaga-lemabga pendukung lainnya.

\footnotetext{
${ }^{1}$ Chairul Fahmi, "Revitalisasi Penerapan Hukum Syariat di Aceh (Kajian terhadap UU No.11 Tahun 2006)” Jurnal TSAQAFAH, Vol. 8, No. 2, Oktober 2012 ,298.

${ }^{2}$ Dede Hendra MR, "Eksitensi Pelanggar Pidana Cambuk, ...viii.

${ }^{3}$ Pasal 3 (1) Keistimewaan merupakan pengakuan bangsa lndonesia yang diberikan kepada Daerah karena perjuangan dan nilai-nilai hakiki masyarakat yang tetap dipelihara secara turun-temurun sebagai landasan spiritual. moral, dan kemanusiaan. (2) Penyelenggaraan Keistimewaan meliputi :

a. penyelenggaraan kehidupan beragama;

b. penyelenggaraan kehidupan adat;

c. penyelenggaraan pendidikan; dan

d. peran ulama dalam penetapan kebijakan Daerah.

Pasal 4 (1) Penyelenggaraan kehidupan beragama di Daerah diwujudkan dalam bentuk pelaksanaan syariat Islam bagi pemeluknya dalam bermasyarakat. (2) Daerah mengembangkan dan mengatur penyelenggaraan kehidupan beragama, sebagaimana dimaksud pada ayat (1). dengan tetap menjaga kerukunan hidup antar umat beragama.

4 Sukron Kamil, dkk. Syariah Islam dan HAM: Dampak Perda Syariah Terhadap Kebebasan Sipil, Hak-Hak Perempuan dan Non-Muslim. (Ciputat:CSRS UIN Jakarta, 2007), 126.
} 
Dari bebrapa lembaga SKPD penegakan Syariat Islam di Aceh, maka penulis akan memfokuskan kepada dua lembaga saja, yaitu Mahkamah Syar'iyah dan Wilayatul Hisbah dengan pertanyaan utama adalah: Bagaimanakah fungsi dan peran Mahkamah Syar'iyah dan Wilayatul Hisbah dalam penegakan Qanun Jinayat dii Aceh?

\section{B. Pembahasan}

Undang-undang No. 11 Tahun 2006 tentang Pemrintahan Aceh (UUPA) memberikan hak untuk membuat sebuah lembaga peradilan guna untuk menunjang kelangsungan penerapan syariat Islam di Aceh. Lembaga tersebut adalah Mahkamah Syar'iyah yang merupakan nomenklatur resmi peradilam Islam di Aceh. ${ }^{5}$ Mahkamah Syar'iyah di Aceh merupakan lembaga peradilan khusus dalam lingkungan peradilan agama, sesuai dengan ketentuan pasal 15 ayat (2) Undang-Undang Nomor 4 Tahun 2004 tentang Kekuasaan Kehakiman yang menjelaskan bahwa, peradilan syariah di Provinsi Nanggroe Aceh Darussalam merupakan peradilan khusus dalam lingkungan peradilan agama sepanjang menyangkut wewenang peradilan agama dan merupakan peradilan khusus dalam lingkup peradilan umum sepanjang menyangkut peradilan umum. ${ }^{6}$

Mahkamah Syar'iyah di Aceh memiliki wewenang yang lebih luas bila dibandingkan dengan peradilan agama ${ }^{7}$ pada umumnya di Indonesia, hal ini dikarenakan mahkamah syar'iyah juga memiliki sebagian dari wewenang penradilan umum. ${ }^{8}$ Tapi walaupun demikian mahkamah syar'iyah tetap merupakan bagian dari sistem peradilan nasional, sebagaimana dijelaskan dalam UUPA pasal 128 ayat (1) Peradilan syariat Islam di Aceh adalah bagian dari sistem peradilan nasional ${ }^{9}$ dalam lingkungan peradilan agama yang dilakukan oleh mahkamah syar'iyah yang bebas dari pengaruh pihak manapun.

5 Jaenal Aripin, Himpunan UU Kekuasaan Kehakiman (Jakarta: Kencana Prenada Media Group, 2010), 795. Lihat juga pasal 1 ayat (1) Keputusan Presiden Republik Indonesia Nomor 11 tahun 2003 tentang Mahkamah Syar'iyah, yang menjelaskan mengenai perubahan nomenklatur peradilan agama di Aceh. "Pengadilan agama yang telah ada di Nanggroe Aceh Darussalam diubah menjadi Mahkamah Syar'iyah”.

${ }^{6}$ Zul Akli,"Eksekusi Tindak Pidana Perjudian (Maisir) Di Mahkamah Syar'iyah Lhokseumawe”, Jurnal Ilmu Hukum, Vol. 3 No. 2, 145.

${ }^{7}$ Rifqi Ridlo Phahlevy, "Mahkamah Syar'iyah Aceh Dalam Konteks NKRI Dan HAM”, Rechtsidee, Vol. 1 No. 1 Tahun 2013,88.

${ }^{8}$ Efa Laela Fakhriah, Yusriza, "Kewenangan Mahkamah Syar'iyah Di Aceh Dihubungkan Dengan Sistem Peradilan Di Indonesia", http://pustaka.unpad.ac.id/wp content/uploads/2014/02/KewenanganMahkamah-Syariyah.pdf. (diakses pada tanggal 17 Maret 2018).

${ }^{9}$ Lihat juga Keputusan Presiden Republik Indonesia Nomor 11 tahun 2003 tentang Mahkamah Syar'iyah. 


\section{Dasar Hukum Pembentukan Mahkamah Syar'iyah}

Sebagai suatu institusi lembaga negara maupun lembaga daerah tentu harus memiliki landasan UU sebagai dasar hukum pendiriannya, begitupula halnya dengan Mahkamah Syar'iyah di Aceh, lembaga ini dibentuk untuk mendukung terselenggaranya penerapan syariat Islam di Aceh, dan resmi berdiri pada hari Selasa 4 Maret 2003. ${ }^{10}$ Dasar hukum pertama, Undang-undang Nomor 44 tahun 1999 tentang Penyelenggaraan Daerah Istimewa Aceh, UU ini menjadi legitimasi bagi Aceh untuk menyelenggarakan: 1) kehidupan beragama; 2) Penyelengaraan Kehidupan adat; 3) penyelengaraan pendidikan dan 4) peran ulama dalam penetapan kebijakan daerah. UU inilah yang menjadi landasan peradilan syariah di Aceh yang kemudian eksitensinya diperkuat kembali oleh UU yang lahir kemudian. ${ }^{11}$ Kedua, Undangundang Nomor 18 Tahun 2001 tentang Otonomi Khusus Bagi Provinsi Daerah Istimewa Aceh sebagai Provinsi Nangroe Aceh Darussalam (UU PNAD) dalam pasal 25 dan 26 dijelaskan bahwa Mahkamah Syar'iyah NAD yang merupakan peradilan syariat Islam sebagai bagian dari sistem peradilan nasional. Mahkamah Syar'iyah adalah lembaga peradilan yang bebas dari pengaruh pihak manapun dalam wilayah PNAD yang berlaku untuk pemeluk agama Islam. ${ }^{12}$ Ketiga, Qanun Nomor 10 tahun 2002 tentang peradilan syariat Islam yang sekali gus merupakan peraturan pelaksanaan yang bersifat lex sepesialis sesuai dengan UU No. 18 Tahun 2001. Keempat, Undang-undang Nomor 4 tahun 2004 tentang Pokok-Pokok Kekuasaan Kehakiman yang menjelaskan bahwa peradilan syariat Islam di Aceh adalah peradilan khusus dalam lingkup peradilan agama dan peradilan khusus dalam lingkup peradilan umum ${ }^{13}$. Kelima, Undang-undang Nomor 11 tahun 2006 tentang Pemerintahan Aceh (UUPA). UUPA ini dapat mengenyampingkan peraturan perundang-undangan yang lain yang sederajat, dengan mengikuti asas lex specialis derogaat lex generalis, sehingga Mahkamah Syar'iyah memiliki kewenangan yang diberikan oleh Undang-undang untuk menerapkan syariat Islam yang diatur dalam qanun.

\section{Pembagian Mahkamah Syar'iyah}

Mahkamah Syar'iyah menganut tiga tingkat peradilan ${ }^{14}$ yang terdiri dari:

10 Tempo, "Pemerintah Resmikan Mahkamah Syariah di Aceh", http://www.tempo.co/ r e ad/news/2003/03/04/0584464/Pemerintah-Resmikan-Mahkamah-Syariah-di-Aceh (diakses pada tanggal 17 Maret 2018).

11 Natangsa Surbakti, "Penegakan Hukum Pidana Islam (Jinayah) Di Provinsi Nanggroe Aceh Darusslam", Jurnal Media Hukum, Vol. 17 No. 2, Desember 2010, 192.

${ }^{12}$ Sirajuddin M, ’Legitimasi Pemberlakuan Syari’at Islam Di NAD: Analisis Prinsip-prinsip Dan Peluang Yuridis Konstitusional”, Sosio-Religia,Vol. 10, No.1, Februari 2012, 82.

${ }^{13}$ Pasal 15 Undang-undang Nomor 4 tahun 2004 tentang Pokok-Pokok Kekuasan Kehakiman.

${ }^{14}$ Sulaiman Tripa, “Otoritas Gampong Dalam Implementasi Syariat Islam Di Aceh”, Media Syariah, Vol. XIV No. 1 Januari-Juni 2012, 45. Lihat juga, Efa Laela Fakhriah, Yusrizal, "Kewenangan Mahkamah Syar'iyah Di Aceh Dihubungkan Dengan Sistem Peradilan Di Indonesia”..., 3. 
a. Mahkamah Syar'iyah kabupaten/sagoe dan kota/banda sebagai pengadilan tingkat pertama;

b. Mahkamah Syar'iyah provinsi sebagai pengadilan tingkat banding yang berada di ibukota provinsi yaitu di Banda Aceh;

c. Sementara untuk tingkat kasasi tetap dilakukan di Mahkamah Agung sebagai pengadilan negara tertinggi. Hal ini sebagaimana disebutkan dalam Pasal 24A UUD NRI 1945, yaitu Mahkamah Agung berwenang mengadili pada tingkat kasasi, menguji peraturan perundang-undangan di bawah undang-undang, dan mempunyai wewenang lainnya yang diberikan oleh undang-undang.

\section{Kekuasaan dan Kewenangan Mahkamah Syar'iyah}

Secara umum kekuasaan dan kewenangan mahkamah syar'iyah adalah kekuasaan dan kewenangan Pengadilan Agama ditambah dengan kekuasaan dan kewenangan lain yang berkaitan dengan kehidupan masyarakat dalam ibadah dan syi'ar Islam yang ditetapkan dalam qanun. ${ }^{15}$

Mahkamah Syar'iyah bertugas dan berwenang memeriksa dan memutuskan perkara yang menjadi kewenangan mahkamah syar'iyah dalam tingkat pertama dan banding. ${ }^{16}$ Mahkamah Syar'iyah provinsi juga bertugas dan berwenang mengadili dalam tingkat pertama dan terakhir sengketa kewenangan antar mahkamah syar'iyah di Provinsi Aceh. Sementara itu, sengketa wewenang antara mahkamah syar'iyah dan pengadilan dalam lingkungan peradilan lain menjadi wewenang Mahkamah Agung Republik Indonesia untuk tingkat pertama dan terakhir. Mahkamah Syar'iyah untuk pengadilan tingkat kasasi dilakukan pada Mahkmah Agung Republik Indonesia. Kewenangan mahkamah syar'iyah di Provinsi NAD ini berlaku bagi pemeluk agama Islam, dan tidak berlaku bagi warga non-muslim. ${ }^{17}$ Dalam pasal 128 ayat (3) UU No. 11 Tahun 2006 dijelaskan bahwa mahkamah syar'iyah berwenang memeriksa, mengadili, memutus, dan menyelesaikan perkara yang meliputi bidang ahwal alsyakhsiyah (hukum keluarga), mu'amalah (hukum perdata), dan jinayah (hukum pidana) yang didasarkan atas syariat Islam.",18

\footnotetext{
15 Jaenal Aripin, Himpunan UU Kekuasaan Kehakiman,...767.

16 Thabary, Muhibuth, Konsep dan Implementasi Wilayatul Hisbah dalam penerapan Syari'at Islam di Nanggroe Aceh Darussalam (Banda Aceh: Disertasi Tidak di terbitkan, Tahun 2007), 35.

${ }^{17}$ Natangsa Surbakti, "Pidana Cambuk dalam Perspektif Keadilan Hukum dan Hak Asasi Manusia di Provinsi Nanggroe Aceh Darussalam” Jurnal Hukum No. 3 Vol. 17 Juli 2010: 456 - 474, 462.

${ }^{18}$ Undang-undang No. 11 Tahun 2006 Tentang Pemerintahan Aceh.
} 


\section{Kewenangan Mahkamah Syar'iyah dalam lingkup Peradilan Agama}

Hukum materil dalam bidang hukum mu'amalah (perdata) yang sebelumnya menjadi kewenangan peradilan agama telah ditetapkan menjadi kewenangan mahkamah syar'iyah di Aceh. ${ }^{19}$ Secara umumm kewenangan mahkamah syar'iyah yang mencakup kewenangan peradilan agama ${ }^{20}$ dapat dibagi menjadi dua kewenangan, pertama, kewenangan relatif yaitu kewenangan untuk menerima, memeriksan dan mengadili serta menyelesaikan suatu perkara yang diajukan kepadanya berdasarkan kepada wilayah hukum pengadilan mana tergugat bertempat tinggal. Kedua kewenangan mutlak, yaitu wewenang badan peradilan dalam memeriksa jenis perkara tertentu yang mutlak tidak dapat diperiksa oleh badan peradilan lain. Hukum acara yang berlaku pada mahkamah syar'iyah sepanjang mengenai ahwal al-syakhsiyah dan mu'amalah adalah hukum acara sebagaimana yang berlaku pada pengadilan dalam lingkungan peradilan agama $^{21}$ sepanjang belum ada qanun yang mengaturnya.

\section{Kewenangan Mahkamah Syar'iyah dalam lingkup Peradilan Umum}

Mahkamah syar'iyah berwenang mengadili dalam bidang hudud, qishash dan ta'zir. Dalam bidang hudud kewenangannya meliputi; zina, qadzaf, mencuri, merampok, minuman keras, nafza, murtad dan pembrontakan. Dalam bidang qishash/diat meliputi: pembunuhan dan penganiayaan. Dalam bidang ta'zir mencukup: judi, penipuan, pemalsuan, khalwat, meninggalkan shalat fardhu dan meninggalkan puasa Ramadhan. ${ }^{22}$ Hukum acara yang berlaku pada mahkamah syar'iyah sepanjang mengenai jinayah adalah hukum acara jinayat yang tertuang dalam Qanun No. 7 Tahun 2013 tentang Hukum Acara Jinayat.

\section{Tugas Pokok dan Fungsi Mahkamah Syar'iyah}

Syariat Islam yang diberlakukan di Aceh mencakup seluruh aspek hukum, baik hukum publik maupun hukum privat. Dalam Qanun Nomor 10 tahun 2002 dijelaskan bahwa kekuasaan dan kewenangan mahkamah syar'iyah mencakup seluruh aspek hukum yang memerlukan penyelesainnya melalui lembaga peradilan. Dalam penjelasan

\footnotetext{
${ }^{19}$ Ainal Hadi, Hukum dan Fenomena Sosial, Aceh Justice Resource Centre, 128.

${ }^{20}$ Rasyid Rizani, "Kedudukan Qanun Jinayat Propinsi Nanggroe Aceh Darussalam Dalam Sistem Hukum Nasional", 15. http://www.slideshare.net/agusmuqtafiy/qanun jinayat-dlm-sistem-hukum-nasional (diakses pada tanggal 30/03/2015).

${ }^{21}$ Pasal 132 Ayat (2) huruf a, UU Nomor 11 Tahun 2006 Tentang Pemerintahan Aceh.

${ }^{22}$ Nurmuklis dan Agus Sanwani, Penerapan Hukum Acara Pidana/Jinayat Mahkamah Syar'iyah di Aceh, (diplusikasikan secara online, 2012) 47. http://www.pa-k u d us.go.id/pdf/EBOOK_PENERAPAN_HUKUM_PIDANA_\%28JINAYAT\%29_MAHKAMAH_SYAR\%27IYA H_DI_ACEH_OK.pdf (dikases pada tanggal 29 Maret 2018).
} 
umum Qanun Nomor 10 tahun 2002 disebutkan bahwa kekuasaan dan kewenangan Mahkamah syar'iyah adalah memeriksa, menyelesaikan dan memutus perkara-perkara pada tingkat pertama dalam bidang al-ahwal as-syakhsiyah, mu'amalah dan jinayah. ${ }^{23}$ Secara umum tugas dan fungsi Mahkamah Syar'iyah dapat dikelompokkan kedalam dua kelompok:

\section{a. Bidang Yustisial}

Dalam bidang yustisial mahkamah syar'iyah bertugas dan berfungsi menerima, memeriksa, memutus dan menyelesaikan perkara-perkara antara orang-orang Islam dibidang al-ahwal al-syakhshiyah (hukum keluarga), mu'amalah (perdata), dan jinayah (pidana). al-ahwal al-syakhshiyah mencakup masalah perkawinan, warisan dan wasiat. Bidang mu'amlah meliputi masalah jual beli, utang - piutang, permodalan (qiradh), bagi hasil, pinjam - meminjam, perkongsian, wakalah, penyitaan, gadai, sewamenyewa dan perburuhan. Sedangkan untuk perkara jinayah mencakup kepada hudud (zina, qadhaf, mencuri, merampok, minuman keras, nafza dan murtad). Qishash yang mecakup masalah pembunuhan dan penganiayaan. Ta'zir yang meliputi masalah judi, penipuan, pemalsuan, khalwat serta meninggalkan shalat dan puasa.

\section{b. Bidang Nonyustisial}

Tugas dan fungsi mahkamah syar'iyah dalam bidang non-yustiyal meliputi: pengawasan jalannya mahkamah syar'iyah, hisab dan rukyat, menyaksikan pengangkatan gubernur dan wakil gubernur, bupati dan wakil bupati, serta memberi nasehat dan pertimbangan hukum bagi lembaga pemerintah yang memerlukan.

\section{Wilayatul Hisbah (WH)}

Wilayatul Hisbah adalah lembaga atau badan yang berwewenang memberitahukan kepada masyarakat tentang peraturan-peraturan yang sudah berlaku dan menyadarkan anggota masyarakat tersebut, agar mematuhi aturan-aturan tersebut supaya tidak dikenakan sanksi atau denda peraturan-peraturan itu (law enforcement). ${ }^{24}$ Menurut Muhammad Mubarak, Hisbah adalah pengawasan administrasi yang dilaksanakan oleh pemerintah dengan menugaskan pejabat khusus untuk mengawasi masalah akhlaq, agama, ekonomi, tepatnya dalam lapangan sosial secara umum dalam rangka mewujudkan keadilan dan keutamaan yang sesuai dengan prinsip-prinsip yang terdapat dalam syariat Islam dan tradisi yang diakui oleh segala tempat

\footnotetext{
${ }^{23}$ Sirajuddin M, "Legitimasi Pemberlakuan Syari'at Islam di NAD: Analisis Prinsip-prinsip dan Peluang Yuridis Konstitusional", SOSIO-RELIGIA, Vol. 10, No.1, Februari 2012, 86.

${ }^{24}$ Al Yasa' Abu Bakar, Wilayatul Hisbah, Polisi Pamong Praja Dengan Kewenangan Khusus di Aceh, (Banda Aceh: Dinas Syari'at Islam Aceh, 2009), 22.
} 
dan zaman ${ }^{25}$. Sedangkan menurut Qanun No. 11 Tahun 2004, yang dimaksud dengan wilayatul hisbah adalah lembaga pembantu tugas kepolisian yang membantu membina, melakukan advokasi dan mengawasi pelaksanaan amar ma'ruf nahi munkar dan dapat berfungsi sebagai polisi khusus (polsus) dan PPNS. ${ }^{26}$

Perdamaian antara Pemerintah Pusat dan Gerakan Aceh Merdeka (GAM) di Helsinki ${ }^{27}$ melahirkan suatu konsekuensi yakni lahirnya UU No. 11 tahun 2006 tentang Pemerintahan Aceh (UUPA), ${ }^{28}$ dalam pasal 244 ayat 1 dan 2 disebutkan bahwa, gubernur, bupati/walikota dalam menegakkan ketertiban dan ketentraman umum dapat membentuk Polisi Pamong Praja (Pol PP). Gubernur, bupati/walikota dalam menegakkan qanun syari'ah dapat membentuk Polisi Wilayatul Hisbah (selanjutnya disebut WH) sebagai bagian dari Polisi Pamong Praja. ${ }^{29}$ WH merupakan suatu lembaga yang diamanatkan untuk menegakkan hukum (law enforcement) dan pengawasan ${ }^{30}$ syariat Islam secara totalitas di Aceh $^{31}$.

Secara kosnepsional masalah pengawasan terhadap pelaksanaan syariat Islam di Aceh dituangkan dalam Qanun No. 11 tahun 2002 tentang pelaksanaan syariat Islam bidang Aqidah, Ibadah dan syi'ar Islam yang diatur dalam Bab VI pasal 14 Ayat 1-5 $5^{32}$ yang menjelaskan bahwa: (1) Untuk terlaksananya syariat Islam bidang Aqidah, Ibadah dan syi'ar Islam, Pemerintah Provinsi, Kab/kota membentuk Wilayatul Hisbah yang berwenang melakukan pengawasan terhadap pelaksanaan qanun ini; (2) Wilayatul Hisbah dapat dibentuk pada tingkat gampong, kemukiman, kecamatan atau wilayah/lingkungan lainnya; (3) Apabila dari hasil pengawasan yang dilakukan oleh wilayatul hisbah sebagaimana dimaksud dalam ayat (2) pasal ini terdapat cukup alasan telah terjadinya pelanggaran terhadap qanun ini, maka pejabat pengawas (wilayatul hisbah) diberi wewenang untuk menegur/menasehati si pelanggar; (4) Setelah upaya menegur/menasehati dilakukan sesuai dengan ayat (3) di atas, ternyata perilaku

${ }^{25}$ Marah Halim, "Eksistensi Wilayatul Hisbah Dalam Sistem Pemerintahan Islam”, Jurnal Ilmiah Islam Futura, Vol. X, No. 2, Februari 2011, 67.

${ }^{26}$ Al Yasa' Abubakar, Syariat Islam di Provinsi Nanggroe Aceh Darussalam Paradigma Kebijakan dan Kegiatan, (Banda Aceh: Dinas Syariat Islam Provinsi Nanggroe Aceh Darussalam, 2005), 358. Lihat juga Pasal 1 Ayat (8) Qanun No. 11 Tahun 2004 Tentang Tugas Fungsional Kepolisian Daerah Nanggroe Aceh Darussalam.

${ }^{27}$ Topo Santoso, "Implementation Of Islamic Crimal Law In Indonesia: Ta'zir, Punishment as A Solution?", Iium Law Journal Vol. 19 No. 1, 2011, 141. Lihat juga Saadan Man, "Transformasi Hukum Islam Komtemporari Di Malaysia Melalui Gagasan Fiqh Malaysia”, Icon-Imad, International Conferece On Islam In Malay Word 2011, 557.

28 Badan Arsip dan Perpustakaan Pemerintah Aceh, "Sejarah Lahirnya Polisi Wilayatul Hisbah", http://arpus.acehprov .go.id/in dex.php/9-uncategorised/121-profil.html (diakses pada tanggal 21 Feb 2018).

${ }^{29}$ Republik Indonesia, Undang-undang Nomor 11 Tahun 2006 Tentng Pemerintahan Aceh.

${ }^{30}$ Dina Afrianty, "Sharia police and the regulating of morality", International Conference Negotiating Diversity in Indonesia, Singapore Management University November 5-6, 2012,3.

${ }^{31}$ Chairul Fahmi, "Revitalisasi Penerapan Hukum Syariat di Aceh (Kajian terhadap UU No.11 Tahun 2006)", Jurnal Tsaqafah, Vol. 8, No. 2, Oktober 2012, 300.

${ }^{32}$ Muhibbuthabry, "Kelembagaan Wilayat al-Hisbah Dalam Konteks Penerapan Syariat Islam di Aceh", Jurnal Ilmiah Peuradeun, Vol. 2 No. 2 Mei 2014, 64. 
sipelanggar tidak berubah, maka pejabat pengawas menyerahkan kasus pelanggaran tersebut kepada pejabat penyidik.(5) Susunan organisasi Kewenangan dan tata kerja Wilayatul Hisbah diatur dengan Keputusan Gubernur setelah mendengar pertimbangan MPU.

Keputusan Gubernur No. 1 Tahun 2004 Tentang Pembentukan Organisasi dan Tata Kerja Wilayatul Hisbah, yang secara resmi membentuk WH dan mengatur peran WH sebagai sumber panduan dan nasihat spiritual bagi masyarakat Aceh $^{33}$ yang meliputi: Memberitahu publik tentang qanun yang terkait dengan hukum syariah; mengawasi kepatuhan atas hukum syariah, menegur, memperingatkan dan memberikan bimbingan moral kepada mereka yang disangka melanggar hukum syariah ${ }^{34}$, berusaha menghentikan tindakan/perilaku yang dicurigai melanggar hukum syariah, menangani pelanggaran-pelanggaran melalui proses adat, dan menyerahkan pelanggaran hukum syariah kepada penyelidik pidana. Dalam Keputusan Gubernur ini disebutkan bahwa susunan organisasi Wilayatul Hisbah, terdiri atas; Wilayatul Hisbah Tingkat Provinsi; Wilayatul Hisbah Tingkat Kabupaten/Kota; Wilayatul Hisbah Tingkat Kecamatan, dan Wilayatul Hisbah Tingkat Kemukiman.

Pada tahun 2007 WH yang sebelumnya berada dibawah Dinas Syariat Islam resmi digabungkan dengan Satuan Polisi Pamong Praja (Satpol PP), Qanun No. 5 tahun 2007 sebagai dasar payung hukumnya ${ }^{35}$. Dalam pasal 202 ayat (1) Qanun No. 5 tahun 2007 dijelaskan bahwa, satuan Polisi Pamong Praja dan Wilayatul Hisbah adalah perangkat Pemrintah Aceh dibidang penegakan pelaksanaan qanun dan syariat Islam, ketentraman, ketertiban umum serta hubungan antar lembaga. ${ }^{36}$

\section{Tugas Pokok, Fungsi dan Kewenangan Wilayatul Hisbah}

Wilayatul Hisbah dalam konteks penerapan syariat Islam di Aceh merupakan suatu lembaga yang tak terpisahkan dari penerapan syariat Islam itu sendiri, sebagai lembaga yang berwenang mengingatkan masyarakat untuk menjalankan amar ma'ruf, WH diberi wewenang untuk mengawasi pemberlakuan syariat Islam serta bertindak tegas terhadap

33 Hirwan Jack, "Efektivitas Wilayatul Hisbah Dalam Pencegahan Aliran Sesat Di Aceh", http://bkpp.acehprov .go.id/ simp egbrr /Art ikel/Artikel05-02-2015/Wilayatul H i s bah_Aceh.pdf , 2. (diakses pada tanggal 16/02/2018).

34 International Crisis Group, "Syari'at Islam Dan Peradilan Pidana Di Aceh", http://www.crisisgroup.org/ /media/Files/asia/south-eastasia/indonesia/Indonesian\% $\quad 20$ tra lations/17_indonesian_s_islamic_law_criminal_justice__indonesian_version.pdf (dikases pada tanggal 25 Maret 2018).

35 Arskal Salim, "Politics, Criminal Justice and Islamisation in Aceh", Melborne Law School, 8. http://www.law.unimelb.edu.au/files/dmfile/salim_final2_forwebsite wo b 1 eed2.pdf (dikases pada tanggal 31 Maret 2018).

${ }^{36}$ Qanun Nomor 5 Tahun 2007 Tentang Susunan Organisasi dan Tata Kerja Dinas, Lembaga Teknis Daerah dan lembaga Daerah Provinsi Aceh.

106 | al-Maslahah: -Volume 15 Nomor 1 Juni 2019 
orang yang berbuat kemunkaran. Sebagai salah satu lembaga pengawasan syariat Islam di Aceh, WH mempunyai tugas pokok, fungsi dan wewenang sebagai berikut:

\section{a. Tugas Pokok Wilayatul Hisbah}

Wilayatul Hisbah mempunyai tugas pokok yaitu memelihara dan menyelenggarakan ketentraman dan ketertiban umum, menegakkan peraturan daerah (qanun), peraturan gubernur, keputusan gubernur, melakukan sosialisasi, pengawasan, pembinaan, penyidikan dan pembantuan pelaksanaan hukuman dalam lingkup peraturan perundang-undangan dibidang syariat Islam. ${ }^{37}$

\section{b. Fungsi Wilayatul Hisbah ${ }^{38}$ :}

1. Pelaksanaan urusan ketatausahaan;

2. Penyusunan program kerja tahunan, jangka menengah dan jangka panjang;

3. Pelaksanaan ketenteraman dan ketertiban umum, penegakan qanun, peraturan gubernur dan keputusan gubernur;

4. Pelaksanaan kebijakan pemeliharaan dan penyelenggaraan ketenteraman, ketertiban umum dan perlindungan masyarakat di daerah;

5. Pelaksanaan kebijakan penegakan qanun, peraturan gubernur dan keputusan gubernur;

6. Pelaksanaan koordinasi pemeliharaan dan penyelenggaraan ketenteraman dan ketertiban umum serta penegakan qanun, peraturan gubernur dan keputusan gubernur dengan aparat kepolisian negara, Penyidik Pegawai Negeri Sipil (PPNS) dan aparatur lainnya;

7. Pengawasan terhadap masyarakat agar mematuhi dan mentaati qanun, peraturan gubernur dan keputusan gubernur.

8. Pelaksanaan penerangan kepada seseorang atau kelompok orang tentang aspek-aspek pelaksanaan syariat Islam;

9. Pelaksanaan sosialisasi kepada seseorang atau kelompok orang tentang adanya peraturan perundang-undangan di bidang syariat Islam;

10. Pelaksanaan upaya-upaya aktif untuk meningkatkan pengetahuan, pemahaman, kesadaran, serta pengamalan masyarakat (seseorang dan kelompok orang) terhadap ketentuan dalam qanun-qanun atau peraturan perundang-undangan di bidang syariat Islam; dan

11. Pengkoordinasian kesatuan-kesatuan Polisi Pamong Praja dan Polisi Wilayatul Hisbah.

\footnotetext{
${ }^{37}$ Pasal 203 Qanun Nomor 5 Tahun 2007.

${ }^{38}$ Pasal 204 Qanun Nomor 5 Tahun 2007.
} 


\section{c. Wewenang Wilayatul Hisbah}

Sesuai dengan ketentuan Pasal 205 Qanun Nomor 5 Tahun 2007 Tentang Susunan Organisasi Dan Tata Kerja Dinas, Lembaga Teknis Daerah, Dan Lembaga Daerah Provinsi Nanggroe Aceh Darussalam dijelaskan bahwa wewenang Wilayatul hisbah adalah, menertibkan dan menindak warga masyarakat atau badan hukum yang menganggu ketentraman dan ketertiban umum; Melakukan pemeriksaan terhadap warga masyarakat atau badan hukum yang melakukan pelanggaran atas qanun, peraturan gubernur dan keputusan gubernur; Melakukan tindakan represif non-yustisial terhadap warga masyarakat atau badan hukum yang melakukan pelanggaran atas qanun, peraturan gubernur dan keputusan gubernur; Menerima laporan atau pengaduan dari seseorang tentang adanya pelanggaran atas qanun atau perundang-undangan di bidang syariat Islam; Melakukan tindakan pertama pada saat kejadian dan di tempat kejadian; Menyuruh berhenti seorang tersangka dan memeriksa tanda pengenal diri tersangka; Menyuruh untuk tidak meninggalkan tempat setiap orang yang berada di tempat kejadian perkara; Melakukan penangkapan, penahanan, penggeledahan, dan penyitaan; Menyamar sebagai pelanggan, pemakai atau pembeli dalam hal ada dugaan pelanggaran larangan khalwat, khamar dan maisir, setelah mendapat surat perintah untuk itu; Melakukan pemeriksaan dan penyitaan surat; Mengambil sidik jari dan memotret seseorang; Memanggil seseorang untuk didengar dan diperiksa sebagai tersangka atau saksi; Mendatangkan seorang ahli yang diperlukan dalam hubungannya dengan pemeriksaan perkara; Menghentikan penyidikan setelah mendapat petunjuk bahwa tidak terdapat cukup bukti atau peristiwa tersebut bukan merupakan pelanggaran syariat dan memberitahukan hal tersebut kepada penuntut umum, penyidik polisi, tersangka sendiri atau keluarganya; dan Melakukan tindakan lain sesuai dengan ketentuan hukum secara bertanggung jawab. ${ }^{39}$

\section{E. Kesimpulan}

Keberadaan dua lembaga utama dalam penegakan Qanun di Aceh diharapkan dapat mendorong efektifitas penerapan syariat Islam di Aceh. Mahkamah Syar'iyah dibentuk untuk mendukung terselenggaranya penerapan syariat Islam di Aceh, dan resmi berdiri pada hari

${ }^{39}$ Pejabat Pengelola Informasi dan Dokumentasi Aceh (PPID-ACEH) https://ppid.acehprov.go.id/v2/dip/.../Qanun\%20Nomor\%205\%20Tahun\%202007.pdf (dikases 15 Januari 2019).

108 | al-Maslahah: -Volume 15 Nomor 1 Juni 2019 
Selasa 4 Maret 2003. Mahkamah Syar'iyah sebagai lembaga peradilan syariah di Aceh masih secara umum kewenangan yang sama dengan Pengadilan Agama di daerah lainnya di Indonesia, hanya saja Mahkamah Syar'iyah diberikan kekuasaan dan kewenangan lain yang berkaitan dengan kehidupan masyarakat dalam ibadah dan syi'ar Islam yang ditetapkan dalam qanun Aceh yang tentunya tidak terdapat di daerah lainnya di Indonesia. Singkatnya mahkamah Syar'iyah di Aceh tidak hanya menangani kasus-kasus perdata Islam saja, akan tetapi juga menangani perkara-perkara pidana (jinayat) selama telah ada Qanun yang mengaturnya.

Adapun dasar hukum pembentukan Mahkamah Syar'iyah di Aceh adalah: Pertama, Undang-undang Nomor 44 tahun 1999 tentang Penyelenggaraan Daerah Istimewa Aceh, Kedua, Undang-undang Nomor 18 Tahun 2001 tentang Otonomi Khusus Bagi Provinsi Daerah Istimewa Aceh sebagai Provinsi Nangroe Aceh Darussalam (UU PNAD) dalam pasal 25 dan 26 dijelaskan bahwa Mahkamah Syar'iyah NAD yang merupakan peradilan syariat Islam sebagai bagian dari sistem peradilan nasional. Mahkamah Syar'iyah adalah lembaga peradilan yang bebas dari pengaruh pihak manapun dalam wilayah PNAD yang berlaku untuk pemeluk agama Islam. Ketiga, Qanun Nomor 10 tahun 2002 tentang peradilan syariat Islam yang sekali gus merupakan peraturan pelaksanaan yang bersifat lex sepesialis sesuai dengan UU No. 18 Tahun 2001. Keempat, Undang-undang Nomor 4 tahun 2004 tentang Pokok-Pokok Kekuasaan Kehakiman yang menjelaskan bahwa peradilan syariat Islam di Aceh adalah peradilan khusus dalam lingkup peradilan agama dan peradilan khusus dalam lingkup peradilan umum . Kelima, Undang-undang Nomor 11 tahun 2006 tentang Pemerintahan Aceh (UUPA).

Wilayatul Hisbah adalah lembaga yang tak terpisahkan dari penerapan syariat Islam di Aceh. Sebagai lembaga yang berwenang mengingatkan masyarakat untuk menjalankan amar ma'ruf, Wilayatul Hisbah diberi wewenang untuk mengawasi pemberlakuan syariat Islam serta bertindak tegas terhadap orang yang berbuat kemunkaran.

Wilayatul Hisbah di Aceh dibentuk berdasarkan Keputusan Gubernur No. 1 Tahun 2004 Tentang Pembentukan Organisasi dan Tata Kerja Wilayatul Hisbah, yang secara resmi membentuk WH dan mengatur peran WH sebagai sumber panduan dan nasihat spiritual bagi masyarakat Aceh yang meliputi: Memberitahu publik tentang qanun yang terkait dengan hukum syariah; mengawasi kepatuhan atas hukum syariah, menegur, memperingatkan dan memberikan bimbingan moral kepada mereka yang disangka melanggar hukum syariah , berusaha menghentikan tindakan/perilaku yang dicurigai melanggar hukum syariah, menangani pelanggaran-pelanggaran melalui proses adat, dan menyerahkan pelanggaran hukum syariah kepada penyelidik pidana. Dalam Keputusan Gubernur ini disebutkan bahwa susunan organisasi Wilayatul Hisbah, terdiri atas; Wilayatul Hisbah Tingkat Provinsi; Wilayatul Hisbah 
Tingkat Kabupaten/Kota; Wilayatul Hisbah Tingkat Kecamatan, dan Wilayatul Hisbah Tingkat Kemukiman.

Pada tahun 2007 Wilayatul Hisbah yang sebelumnya berada dibawah Dinas Syariat Islam resmi digabungkan dengan Satuan Polisi Pamong Praja (Satpol PP), Qanun No. 5 tahun 2007 sebagai dasar payung hukumnya . Dalam pasal 202 ayat (1) Qanun No. 5 tahun 2007 dijelaskan bahwa, satuan Polisi Pamong Praja dan Wilayatul Hisbah adalah perangkat Pemrintah Aceh dibidang penegakan pelaksanaan qanun dan syariat Islam, ketentraman, ketertiban umum serta hubungan antar lembaga

\section{DAFTAR PUSTAKA}

Abu Bakar, Al Yasa'. Wilayatul Hisbah, Polisi Pamong Praja Dengan Kewenangan Khusus di Aceh, (Banda Aceh: Dinas Syari'at Islam Aceh, 2009).

Abubakar, Al Yasa'. Syariat Islam di Provinsi Nanggroe Aceh Darussalam Paradigma Kebijakan dan Kegiatan, (Banda Aceh: Dinas Syariat Islam Provinsi Nanggroe Aceh Darussalam, 2005).

Afrianty, Dina. "Sharia police and the regulating of morality", International Conference Negotiating Diversity in Indonesia, Singapore Management University November 5-6, 2012.

Akli, Zul. "Eksekusi Tindak Pidana Perjudian (Maisir) Di Mahkamah Syar'iyah Lhokseumawe", Jurnal Ilmu Hukum, Vol. 3 No. 2, 145.

Aripin, Jaenal. Himpunan UU Kekuasaan Kehakiman. Jakarta: Kencana Prenada Media Group, 2010.

Badan Arsip dan Perpustakaan Pemerintah Aceh, "Sejarah Lahirnya Polisi Wilayatul Hisbah", http://arpus.acehprov .go.id/in dex.php/9-uncategorised/121-profil.html.

Efa Laela Fakhriah, Yusriza, "Kewenangan Mahkamah Syar'iyah Di Aceh Dihubungkan Dengan Sistem Peradilan Di Indonesia", http://pustaka. unpad.ac.id/wpcontent/uploads/2014/02/Kewenangan-Mahkamah-Syariyah.pdf.

Fahmi, Chairul. "Revitalisasi Penerapan Hukum Syariat di Aceh (Kajian terhadap UU No.11 Tahun 2006)" Jurnal TSAQAFAH, Vol. 8, No. 2, Oktober 2012.

Fahmi, Chairul. "Revitalisasi Penerapan Hukum Syariat di Aceh (Kajian terhadap UU No.11 Tahun 2006)", Jurnal Tsaqafah, Vol. 8, No. 2, Oktober 2012.

Hadi, Ainal. Hukum dan Fenomena Sosial, Aceh Justice Resource Centre, 128.

Halim, Merah "Eksistensi Wilayatul Hisbah Dalam Sistem Pemerintahan Islam”, Jurnal Ilmiah Islam Futura, Vol. X, No. 2, Februari 2011.

Hirwan Jack, "Efektivitas Wilayatul Hisbah Dalam Pencegahan Aliran Sesat Di Aceh", http://bkpp.acehprov .go.id/ simp egbrr /Art ikel/Artikel05-02-2015/Wilayatul H is bah Aceh.pdf. 
International Crisis Group, "Syari'at Islam Dan Peradilan Pidana Di Aceh", http://www.crisisgroup.org/ /media/Files/asia/southeastasia/indonesia/Indonesian\% 20 tra nslations/17 indonesian_s_islamic_law criminal justice_indonesian_version.pdf.

Kamil, Sukron dkk. Syariah Islam dan HAM: Dampak Perda Syariah Terhadap Kebebasan Sipil, Hak-Hak Perempuan dan Non-Muslim. Ciputat:CSRS UIN Jakarta, 2007.

Man, Saadan. “Transformasi Hukum Islam Komtemporari Di Malaysia Melalui Gagasan Fiqh Malaysia”, Icon-Imad, International Conferece On Islam In Malay Word 2011.

Muhibbuthabry, "Kelembagaan Wilayat al-Hisbah Dalam Konteks Penerapan Syariat Islam di Aceh”, Jurnal Ilmiah Peuradeun, Vol. 2 No. 2 Mei 2014.

Nasution, Lahmuddin. Pembaruan Hukum Islam dalam Mazhab Syafi'i, Cet. I. Bandung: Remaja Rosdakarya, 2001.

Natangsa Surbakti, "Penegakan Hukum Pidana Islam (Jinayah) Di Provinsi Nanggroe Aceh Darusslam”, Jurnal Media Hukum, Vol. 17 No. 2, Desember 2010, 192.

Natangsa Surbakti, "Pidana Cambuk dalam Perspektif Keadilan Hukum dan Hak Asasi Manusia di Provinsi Nanggroe Aceh Darussalam” Jurnal Hukum No. 3 Vol. 17 Juli 2010: $456-474,462$.

Nurmuklis dan Agus Sanwani, Penerapan Hukum Acara Pidana/Jinayat Mahkamah Syar'iyah di Aceh, (diplusikasikan secara online, 2012), 47. http://www.pa-k u dus.go.id/pdf/EBOOK_PENERAPAN_HUKUM_PIDANA_\%28JINAYAT\%29_MA HKAMAH_SYAR\%27IYAH_DI_ACEH_OK.pdf.

Pejabat Pengelola Informasi dan Dokumentasi (PPID-Aceh), https://ppid.acehprov.go.id/v2/dip/.../Qanun\%20Nomor\%205\%20Tahun\%202007.pdf.

Pemerintah Aceh, Qanun No. 11 Tahun 2004 Tentang Tugas Fungsional Kepolisian Daerah Nanggroe Aceh Darussalam.

Pemerintah Aceh, Qanun Nomor 5 Tahun 2007 Tentang Susunan Organisasi dan Tata Kerja Dinas, Lembaga Teknis Daerah dan lembaga Daerah Provinsi Aceh.

Republik Indonesia, Undang-undang Nomor 11 Tahun 2006 Tentng Pemerintahan Aceh.

Republik Indonesia, Undang-undang Nomor 18 Tahun 2001 tentang Otonomi Khusus bagi Propinsi Daerah Istimewa Aceh sebagai Propinsi Nanggroe Aceh Darussalam (NAD).

Republik Indonesia, Undang-undang Nomor 44 tahun 1999 tentang Penyelenggaraan Keistimewaan Aceh.

Rifqi Ridlo Phahlevy, "Mahkamah Syar'iyah Aceh Dalam Konteks NKRI Dan HAM", Rechtsidee, Vol. 1 No. 1 Tahun 2013, 88.

Rizani, Rasyid. "Kedudukan Qanun Jinayat Propinsi Nanggroe Aceh Darussalam Dalam Sistem Hukum Nasional", 15. http://www.slideshare.net/ agusmuqtafiy/qanunjinayatdlm-sistem-hukum-nasional.

Salim, Arskal. "Politics, Criminal Justice and Islamisation in Aceh", Melborne Law School, http://www.law.unimelb.edu.au/files/dmfile/salim_final2_forwe bsite wo b 1 eed2.pdf .

Santoso, Topo. 'Implementation Of Islamic Crimal Law In Indonesia: Ta'zir, Punishment as A Solution?", Iium Law Journal Vol. 19 No. 1, 2011. 
Sirajuddin M, "Legitimasi Pemberlakuan Syari'at Islam Di NAD: Analisis Prinsip-prinsip Dan Peluang Yuridis Konstitusional”, Sosio-Religia,Vol. 10, No.1, Februari 2012, 82.

Sirajuddin M, "Legitimasi Pemberlakuan Syari'at Islam di NAD: Analisis Prinsip-prinsip dan Peluang Yuridis Konstitusional”, SOSIO-RELIGIA, Vol. 10, No.1, Februari 2012.

Sulaiman Tripa, "Otoritas Gampong Dalam Implementasi Syariat Islam Di Aceh", Media Syariah, Vol. XIV No. 1 Januari-Juni 2012.

Tempo, "Pemerintah Resmikan Mahkamah Syariah di Aceh", http://www.tempo.co/ r e ad/news/2003/03/04/0584464/Pemerintah-Resmikan-Mahkamah-Syariah-di-Aceh.

Thabary, Muhibuth, Konsep dan Implementasi Wilayatul Hisbah dalam penerapan Syari'at Islam di Nanggroe Aceh Darussalam (Banda Aceh: Disertasi Tidak di terbitkan, Tahun 2007), 35 . 